DOI https://doi.org/10.30525/978-9934-588-80-8-1.44

\title{
ПСИХОЛОГІЧНИЙ АСПЕКТ ДИСТАНЦІЙНОГО НАВЧАННЯ СТУДЕНТІВ-ФІЛОЛОГІВ
}

\author{
Ковпік C. I. \\ доктор філологічних наук, \\ професор кафедри української та зарубіжної літератур \\ Криворізький державний педагогічний університет \\ Мельник Н. Г. \\ кандидат філологічних наук, \\ доиент кафедри украӥнської та зарубіжної літератур \\ Криворізький державний педагогічний університет \\ м. Кривий Ріг, Дніпропетровська область, Украӥна
}

Метою розвідки $\epsilon$ спроба виявити особливості психологічної адаптації студентів-філологів в умовах віртуального спілкування під час дистанційного навчання. Як відомо, в Україні дистанційне навчання регулюється Концепцією розвитку дистанційної освіти України та Положенням про дистанційну освіту МОН України ще від 21 січня 2004 року. Але до подій пов'язаних з пандемією короновірусу не тільки в Україні, а й у всьому світі, технології дистанційного навчання, як і психологічний аспект цієї форми навчання, залишалися на задвірках психолого-педагогічної думки. I ось в останні тільки півроку з'явилося чимало наукових спостережень та досліджень, в яких учені презентують різноманітні способи удосконалення дистанційного навчання, а також пропонують шляхи психологічної підтримки студентів та створення комфортних умов, за яких сформований сприятливий психологічний клімат дозволить студентові виробити індивідуальний стиль засвоєння знань в умовах віртуального контенту.

Автори монографії «Дистанційне навчання: психологічні засади» наголошують на тому, що в умовах дистанційної освіти дуже важливо налагодити механізм зворотного зв'язку між викладачем та студентом, а тому навчання у такий спосіб перетворюється на спільну діяльність та взаємодопомогу. Для студентів-філологів, у яких основним засобом здобуття знань $є$ слово та словесна комунікація, психологічна адаптація до сприймання навчальної інформації, а головне - відтворення нових знань, розвиток зв'язного мовлення, дискусійне обговорення творів художньої літератури потребує особливої психологічної підготовки. 
На нашу думку, успішній психологічній адаптації студентівфілологів в умовах дистанційного навчання сприяють такі фактори:

- чітке планування та організація навчальної діяльності в умовах дистанційної освіти;

- передбачення можливих збоїв в обладнанні, а тому включення до планів семінарських занять, в умовах дистанційного навчання, альтернативних варіантних завдань, котрі доцільно викладачеві обговорити зі студентами заздалегідь.

Відзначимо, що освіта за допомогою засобів та технологій дистанційного навчання вимагає певних методологічних та психологічних вимог щодо побудови курсів, часу на підготовку навчального матеріалу викладачем, спеціалізованої організації роботи студентів, врахування специфіки курсу, побудови та презентації матеріалів у веб-середовищі дистанційного навчання, включаючи також психологічні особливості роботи студентів. Нині існує дві форми навчання із використання технологій дистанційного навчання - безпосередньо-контактна форма, котра представлена у вигляді відеолекцій, вебінарів, чатів, мультимедійних лекційних матеріалів тощо та дистанційна форма, наприклад, Moodle.

Як показав цьогорічний досвід дистанційного навчання на платформі Zoom студентів-філологів факультету української філології Криворізького державного педагогічного університету з точки зору забезпечення належного психологічного клімату, така форма навчання мала низку переваг: колективне обговорення текстів творів художної літератури, можливість поставити запитання, доступ студентів i викладачів до демонстраційних екранів один одного, запис заняття.

Проте, відзначимо, що спочатку студентам-філологам було дуже складно налаштуватися на сприйняття один одного через монітор, усвідомити, що вони не говорять самі з собою, а тому під час таких занять відчувалася розгубленість та помітне розсіювання їхньої уваги, а це утруднювало процес контролю цілеспрямованого потоку інформації викладачем.

Наступною перепоною було те, що студенти-філологи одночасно включалися у процес відтворення навчальної інформації, що суттєво дезорієнтувало викладача під час оцінювання їхніх знань. Ось тому ті студенти, які не встигали відповідати усно, писали відповіді в чаті. Усі ці названі недоліки помітно погіршували психологічний клімат під час дистанційної комунікації. Студенти нервували, проявлялася невпевненість у відповідях, зростало роздратування. Але в процесі такого навчання довелося швидко перелаштовуватися, 3 організовуватися, і навчитися корегувати нові умови навчання. I тут, на нашу 
думку, добре спрацювала злагоджена взаємодія між викладачем та студентами. Важливо було виробити єдині правила поведінки під час відеоконференцій з допомогою додатка Zoom. Так, студенти почали синхронно вимикати мікрофони під час виступів свої колег, структурувати та конкретизувати зміст відповідей, повідомлень. Виробили уміння дотримуватися по черговості відповідей, контролювати реакцію не тільки викладача, а й своїх одногрупників.

Усе це згодом мало позитивні результати. 3 кожним заняттям студенти демонстрували виваженість, стриманість, бажання працювати злагоджено, ефективно, а головне - оперативно, адже час відеоконференції був чітко регламентованим.

Окремо необхідно акцентувати увагу і на особливостях спілкування в умовах дистанційного навчання, адже такий формат спілкування часто сприймається користувачами як «знеособлений», котрий вимагає насправді дещо більшого самоконтролю та самоорганізації. I тут варто задіяти етикет Інтернет-спілкування. I хоча правила цього різновиду етикету поки ще не виписані, тож варто звертати увагу студентів на те, що необхідно дотримуватися правил ввічливого та шанобливого ставлення один до одного як і при особистому спілкуванні, враховувати той факт, що спілкування відбувається в кіберпросторі, а його межі набагато ширші, ніж межі звичайного людського спілкування, дотримуватися правил конфіденційності та авторства презентованої інформації.

Отже, як показав досвід, в умовах дистанційного навчання необхідно обов'язково забезпечувати відповідний психолого-педагогічний супровід. Слід пам'ятати, що цільова аудиторія дистанційного навчання - це особистості зі сформованою самосвідомістю, яких варто мотивувати до самонавчання. Спостереження на роботою студентів-філологів в умовах дистанційного навчання дозволили виявити такі особливості їхнього сприймання навчальної інформації:

- сприймають інформацію переважно у зорових образах;

- манера спілкування динамічна та емоційна;

- легко запам'ятовують вербальні інструкції;

- розвинена уява;

- занадто часто відволікаються на сторонны звуки;

- дуже контактні;

- важко переживають стреси та дискомфорт, пов'язані 3 нерозумінням навчального матеріалу.

Тож усі зазначені особливості сприйняття навчальної інформації студентами-філологами під час дистанційного навчання дозволяють їх 
класифікувати як візуалів та аудиалів, які добре сприймають письмову та усну інформацію, активні у взаємодії 3 іншими студентами. Найкраще сприймають інформацію, презентовану в емоційних образах.

Отже, нині в умовах вимушеного дистанційного навчання перед викладачем постає низка проблем, пов'язаних 3 ефективною підготовкою до організації дистанційного навчання: готовність та мобільність викладача працювати в режимі он-лайн та забезпечувати належний психолого-педагогічний супровід; підготовка навчального матеріалу, 3 урахуванням індивідуальних та психологічних особливостей студентів, створення належних умов у віртуальному навчальному середовищі. Відзначимо, що перед сучасним викладачем ЗВО в умовах дистанційної освіти існує потреба постійного удосконалення своїх навичок роботи 3 різними програмами та сайтами в мережі Інтернет, а також необхідність часто оновлювати навчальний матеріал. Викладачеві варто контролювати психологічні особливості сприймання та осмислення навчального матеріалу певним контингентом студентів, враховуючи їхні індивідуальні особливості при розробці дистанційного курсу.

Тож зміст дистанційного курсу повинен складатися із значної кількості диференційованих завдань, щоб студенти з різними типами нервової системи могли повноцінно себе в ньому реалізувати та отримати якісні знання.

На нашу думку, зараз розпочався активний процес створення психологічно та педагогічно доцільних інтерактивних завдань для різних навчальних дисциплін дистанційно, а тому в цьому напрямку будуть продовжуватися подальші дослідження.

\section{Література:}

1. Дистанційне навчання: психологічні засади : монографія / [М.Л. Смульсон, Ю.І. Машбиць, М.І. Жалдак та ін.] ; за ред. М.Л. Смульсон. Кіровоград : Імекс-ЛТД, 2012. 240 с. 